\title{
Marine polyunsaturated fatty acids and cancer therapy
}

\author{
V C Vaughan ${ }^{1}$, M-R Hassing ${ }^{1}$ and P A Lewandowski ${ }^{*}{ }^{* 1}$ \\ ${ }^{1}$ School of Medicine, Deakin University, 75 Pigdons Road, Waurn Ponds, Victoria 3216, Australia
}

Polyunsaturated fatty acids (PUFAs) derived from marine sources, including eicosapentaenoic acid (EPA) and docosahexaenoic acid (DHA), are widely consumed as supplements within the community. However, the use of marine PUFAs in a therapeutic context is also increasing in patients receiving treatment for a range of cancer types. On balance, the literature suggests that marine PUFAs have potential as an effective adjuvant to chemotherapy treatment, may have direct anticancer effects, and may help ameliorate some of the secondary complications associated with cancer. Although a range of doses have been trialled, it would appear that supplementation of fish oil ( $>3 \mathrm{~g}$ per day) or EPA/DHA ( $>1 \mathrm{~g}$ EPA and $>0.8 \mathrm{~g}$ DHA per day) is associated with positive clinical outcomes. However, further research is still required to determine the mechanisms via which marine PUFAs are mediating their effects. This review summarises our current understanding of marine PUFAs and cancer therapy.

Investigations in a variety of cancer types with a range of chemotherapy agents have reported greater efficacy of chemotherapy when marine n-3 long-chain polyunsaturated fatty acids (LCPUFAs) are added to the diet (Murphy et al, 2011). The mechanisms of action of these antineoplastic agents vary, suggesting that n-3 LCPUFAs modulate responses via diverse range of mechanisms. The n-3 LCPUFAs are also suggested to have antitumour effects including inhibition of angiogenesis and metastasis (Baracos et al, 2004); however, the specific mechanisms behind these effects have not been elucidated. Furthermore, n-3 LCPUFAs have been implicated in decreasing the severity of secondary cancer complications including cancer cachexia. Regardless of the exact mechanisms, previous studies suggest that n-3 LCPUFAs may have potential as an effective adjuvant to chemotherapy treatment, may have direct anticancer effects, and may help to ameliorate some of the secondary complications associated with cancer. In this review we briefly describe the chemical structure of n-3 LCPUFAs, the anticancer effects associated with their use in cancer patients, and some of the potential benefits they may have in patients who develop cancer cachexia.

\section{MARINE PUFAS}

Marine PUFAs are divided into two classes: omega-3 (n-3) and omega- 6 (n-6); the n-3 and n-6 indicate the position of the first double bond with regard to the terminal methyl end of the molecule (Gurr et al, 2008). The n-3 and n-6 PUFAs are stored in membrane phospholipids (Schmitz and Ecker, 2008), and are responsible for numerous cellular functions including cell membrane structure, fluidity, signalling, and cell-to-cell interaction (Colomer et al, 2007). They also regulate other bodily functions including blood pressure, blood clotting, and nervous system function and development (Wall et al, 2010). The n-3 and n- 6 fatty acids are considered to be essential nutrients and are required in the diet. Although the synthesis of longer, more saturated n-3 fatty acids within human tissues is possible when provided with the precursor linolenic acid, the rate of synthesis to longer more unsaturated fatty acids in humans is limited (Schmitz and Ecker, 2008). Eicosapentaenoic acid (EPA; 20:5 n-3) and docosahexaenoic acid (DHA; 22:6 n-3) are long-chain n-3 fatty acids (Gurr et al, 2008) found in all fish species, with oily fish from cold climates containing the highest levels of EPA and DHA, although levels differ depending on a number of factors such as environment and fat content (Wall et al, 2010).

Arachidonic acid (AA) is a major intermediate derived from n-6 fatty acids that competes for the same metabolic pathway as EPA, as they are both catalysed by the same enzymes (Schmitz and Ecker, 2008), and therefore when high levels of EPA are consumed in the diet, AA levels are reduced and in part substituted by EPA (Wall et al, 2010). The reverse also occurs when high levels of AA or low levels of EPA are consumed in the diet (Wall et al, 2010). In addition to playing important roles in cellular and bodily functions, n-3 and n-6 are precursors to eicosanoids that have a

*Correspondence: Dr PA Lewandowski; E-mail: paul.lewandowski@deakin.edu.au

Received 8 May 2012; revised 15 November 2012; accepted 23 November 2012;

published online 8 January 2013

(C) 2013 Cancer Research UK. All rights reserved 0007-0920/13

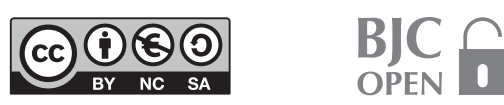


vital function in regulating inflammatory processes (Wall et al, 2010). Polyunsaturated fatty acids are stored in cellular membranes, and are released via hydrolysis and esterification by phospholipase $\mathrm{A}_{2}\left(\mathrm{PLA}_{2}\right)$ before metabolism into eicosanoids (Schmitz and Ecker, 2008). Eicosanoids can be divided into four categories: prostaglandins, thromboxanes, leukotrienes, and hydroxyeicosatetraenoic acids (Wall et al, 2010), which differ in action depending on if they are a derivative of AA or EPA. Eicosanoids from $\mathrm{AA}$ are responsible for inducing pro-inflammatory, proarrhythmic, and vasoconstrictive responses, whereas eicosanoids from EPA have the contrasting effects of anti-inflammatory, antiarrhythmia, and vasodilative responses (Schmitz and Ecker, 2008).

\section{ANTICANCER ACTIONS OF MARINE PUFAS}

Both EPA and DHA have received much attention recently because of the emergence of studies reporting their effects as broadspectrum health-promoting agents, including their use in the prevention and treatment of cancer. Table 1 summaries key clinical studies that have investigated the use of n-3 LCPUFAs in the treatment of cancer and treatment or prevention of cachexia.

Many epidemiological studies have suggested that a diet high in n-3 LCPUFA, such as the Japanese and Mediterranean diets, has lower incidences of cancer (Baracos et al, 2004; Gerber, 2012). Although it is difficult to draw solid conclusions regarding their benefit from epidemiological studies, prospective studies assessing n-3 LCPUFA intake for extended periods have shown inverse associations between intake and cancer risk. A study of over 90000 subjects in Japan showed a significant, dose-dependent decrease in risk of development of hepatocellular carcinoma in people with a higher fish and n-3 PUFA intake, even in a high-risk group after adjustment for additional risk factors (Sawada et al, 2012). Hepatocellular carcinoma is an inflammatory-linked cancer, triggered by hepatitis virus infection and toxin exposure, and therefore the anti-inflammatory action of $n-3$ s may be responsible for the decrease shown. A prospective study over 22 years studying fish intake and colorectal cancer risk in American physicians showed similar results, with lower risk of cancer development associated with higher n-3 PUFA intake (Hall et al, 2008). These associations persisted after controlling for known risk factors and possible confounding issues, indicating that there is a strong probability that the effect was indeed caused by the consumption of n-3-rich foods and supplements. Both these studies and others have proposed the anti-inflammatory properties of n-3 fatty acids as the likely mechanism for cancer prevention (Baracos et al, 2004; Hall et al, 2008; Sawada et al, 2012). The World Cancer Research Fund/American Institute for Cancer Research (2007) Expert Report provides a comprehensive review of further studies relating to the prevention of cancer through food, nutrition, and physical activity, including marine-derived n-3 LCPUFAs such as EPA and DHA (AICR and WCRF, 2007). Numerous in vitro and in vivo studies have demonstrated that n-3 LCPUFA supplementation, in particular EPA and DHA, can inhibit tumour growth through a variety of other proposed mechanisms, including apoptosis, inhibition of angiogenesis, and alterations to cell signalling, all of which have been implicated in the reduced risk of cancer development seen in study populations with high n-3 LCPUFA intake (Baracos et al, 2004).

Several experimental studies utilising a variety of chemotherapeutic agents and tumour types have reported a greater efficacy of chemotherapy with the addition of n-3 LCPUFA. In particular, EPA and DHA modulate this response via diverse mechanisms (Baracos et al, 2004). Eicosapentaenoic acid and DHA have previously been shown to increase tumour sensitivity to irinotecan therapy and protect nontarget tissues, including a reduction of gastrointestinal toxicity (Baracos et al, 2004). More recently, Murphy et al 2011 have shown that the administration of $2.5 \mathrm{~g} \mathrm{day}^{-1}$ of an EPA + DHA supplement to non-small cell lung cancer (NSCLC) patients undergoing platinum-based chemotherapy caused a two-fold increase in therapy response rate and clinical benefit when compared with patients undergoing the same treatment without additional supplementation (Murphy et al, 2011). Patients in the supplement group were also able to undertake on average an additional 3 weeks of chemotherapy, and showed a trend toward increased survival (Murphy et al, 2011). Improved chemotherapy outcomes have been observed in breast cancer patients undergoing anthracycline-based chemotherapy when a daily DHA supplement was highly incorporated into circulating phospholipids (Bougnoux et al, 2009). The potential for DHA supplementation to sensitise tumours to treatment was suggested because of high antitumour activity observed with high incorporation of DHA in plasma phospholipids. This may be due to membrane enrichment with the highly peroxidisable DHA, leading to increased peroxidation of membranes caused by oxidative stress induced by the cancer therapy (Bougnoux et al, 2009; Das, 2011). The addition of n-3 LCPUFA has been demonstrated to improve tumour toxicity, reduce off-target toxicity, and act to protect off-target tissues. Because of reduced symptom burden and toxicity, longer treatment times are achievable, leading to extended survival duration, and providing a strong rationale for the inclusion of marine PUFA as a concurrent treatment during chemotherapy.

Supplementation with marine-sourced n-3 PUFAs has been shown to exert some benefit on the general health and quality of life (QoL) in cancer patients. A recent study in NSCLC patients showed that daily supplementation with EPA/DHA, in conjunction with standard treatment, improved QoL, physical function, cognitive function, and global health status compared with control patients (van der Meij et al, 2012). The study also demonstrated that patients undergoing the treatment tended to have higher physical activity than the control group. The EPA supplementation in lung cancer patients has also shown improved general wellbeing after a 60-day period, with patients in one study showing significant improvements in body weight, energy intake, appetite, and QoL (Elia et al, 2006). Patients had improved nutritional status, and a reduction in circulating acute-phase proteins, indicating reduced inflammation, as shown in previously mentioned studies. However, results from a recent study of enteral EPA and DHA supplementation post surgery in oesophagogastric cancer demonstrated that although circulating levels of n-3 fatty acids were increased, there was no improvement in morbidity, mortality, or length of hospital stay (Sultan et al, 2012), indicating that the benefit of n-3 LCPUFA supplementation is not universal, and may be dependent upon when supplementation is provided during the progression of cancer or treatment course.

As previously discussed, inflammation can be a key factor in cancer, and poses a critical target for cancer therapy. The importance of the circulating n-3 to n-6 fatty acid ratio in blood has been highlighted by a study in breast cancer survivors investigating the effect of PUFA on multidimensional fatigue and inflammation (Alfano et al, 2012). Physical fatigue symptoms and impact were significantly associated with increased inflammation, with higher C-reactive protein (CRP) levels associated with greater risk of fatigue even after adjustment for multiple co-risk factors. Increased $n-3$ relative to $n-6$ in the diet was associated with a clinically significant reduction in inflammation, whereas high n-3 intake also correlated with reduced behavioural, sensory and cognitive aspects of fatigue. The reduced risk of fatigue with increased n-3 consumption implies an inflammation-mediated association between PUFA consumption and fatigue in this population. As increased inflammation is associated with decreased survival intervals for breast cancer patients (Alfano et al, 2012), this 
Table 1. Use of marine-derived n-3 LCPUFAs in cancer prevention, cancer therapy, and the prevention and treatment of cancer cachexia

\begin{tabular}{|c|c|c|c|}
\hline Author & Design & Objectives & Outcomes \\
\hline $\begin{array}{l}\text { Alfano et al } \\
\text { (2012) }\end{array}$ & $\begin{array}{l}\text { Breast cancer survivors }(n=633) \text { completed } \\
\text { food frequency questionnaire and blood test } \\
\text { ( } 30 \text { months post diagnosis), Piper Fatigue } \\
\text { Scale, and Short Form-36 vitality scale } \\
\text { ( } 39 \text { months post diagnosis). }\end{array}$ & $\begin{array}{l}\text { To investigate the effects of } n-3 \text { and } n-6 \text { PUFA } \\
\text { intake on fatigue and inflammation in breast } \\
\text { cancer survivors. By measuring } n-3 \text { and } n-6 \\
\text { intake, fatigue using a piper fatigue scale and } \\
\text { analysing CRP levels. }\end{array}$ & $\begin{array}{l}\text { High CRP increased risk of fatigue. Higher n-6 } \\
\text { intake compared with n-3 intake associated } \\
\text { with higher CRP and higher risk of fatigue. } \\
\text { Reduced risk of fatigue with increased n-3 } \\
\text { consumption implies an inflammation- } \\
\text { mediated association between PUFA } \\
\text { consumption and fatigue in this population. }\end{array}$ \\
\hline $\begin{array}{l}\text { Bayram et al } \\
\text { (2009) }\end{array}$ & $\begin{array}{l}\text { Paediatric patients with a range of malignant } \\
\text { cancers }(n=52) \text { were randomised to a } \\
\text { prospective, single-centre, open-label study to } \\
\text { either: E group: Protein and energy-rich oral } \\
\text { supplement containing } 2.18 \mathrm{~g} \text { EPA }(n=33) \text { or } \\
\text { C group: Patients usual dietary care }(n=19) \text {. } \\
\text { Patients started treatment from clinical } \\
\text { diagnosis with patients continuing for } 3 \text { months } \\
\text { and a subgroup continuing for } 6 \text { months. }\end{array}$ & $\begin{array}{l}\text { To assess the effects of an energy-dense oral } \\
\text { supplement containing EPA on body weight } \\
\text { and remission rates in paediatric patients with } \\
\text { malignant cancers, by measuring body weight } \\
\text { and remission rates. }\end{array}$ & $\begin{array}{l}\text { Remission rates at } 3 \text { months of E group were } \\
\text { significantly higher compared with C group. } \\
\text { The E group experienced significantly less } \\
\text { loss of body weight and BMI compared with } \\
\text { C group. Important to note that the above } \\
\text { outcomes were predominantly seen in } \\
\text { leukaemia patients compared with solid } \\
\text { cancer patients. }\end{array}$ \\
\hline $\begin{array}{l}\text { Bougnoux } \\
\text { et al (2009) }\end{array}$ & $\begin{array}{l}\text { Open-label, single-arm phase II study } \\
\text { assessing safety and efficacy in metastatic } \\
\text { breast cancer patients }(n=25) \text { undergoing } \\
\text { chemotherapy. DHA }(1.8 \mathrm{~g}) \text { daily with } \\
\text { anthracycline-based chemotherapy. }\end{array}$ & $\begin{array}{l}\text { To investigate the efficacy and safety of adding } \\
\text { DHA to an oral supplement ROS generating } \\
\text { chemotherapy treatment, by measuring } \\
\text { response rate and survival of breast cancer } \\
\text { patients. }\end{array}$ & $\begin{array}{l}\text { No adverse side effects associated with DHA } \\
\text { supplementation during chemotherapy. } \\
\text { Higher plasma DHA concentrations were } \\
\text { associated with increased clinical benefit and } \\
\text { extended survival duration. The DHA } \\
\text { supplementation during chemotherapy may } \\
\text { improve treatment response via } \\
\text { chemosensitisation of tumours by DHA } \\
\text { membrane incorporation and improve } \\
\text { survival in breast cancer patients. }\end{array}$ \\
\hline $\begin{array}{l}\text { Cerchietti } \\
\text { et al (2007) }\end{array}$ & $\begin{array}{l}\text { Patients with advanced non-small cell lung } \\
\text { cancer }(n=22) \text { were randomised to an } \\
\text { unblinded, placebo-controlled study to receive } \\
6 \text { weeks of treatment in either: E group: fish oil } \\
\text { (18\% EPA and } 12 \% \text { DHA) } 6 \mathrm{~g} \text { and celecoxib } \\
(n=10) . \text { C group: fish oil }(18 \% \text { EPA and } 12 \% \\
\text { DHA) } 6 \mathrm{~g} \text { and placebo }(n=12) \text {. }\end{array}$ & $\begin{array}{l}\text { To measure the effects of a multimodal } \\
\text { treatment (including fish oil) on a group of } \\
\text { Systemic Immune-Metabolic Syndrome (SIMS) } \\
\text { symptoms in non-small cell lung cancer } \\
\text { patients. Symptoms assessed included } \\
\text { cachexia anorexia, nausea, fatigue, and } \\
\text { appetite. }\end{array}$ & $\begin{array}{l}\text { E group showed a significant increase in body } \\
\text { weight compared with baseline, C group } \\
\text { showed a decrease in body weight. Appetite } \\
\text { significantly increased in both groups. } \\
\text { Fatigue and CRP levels significantly } \\
\text { decreased in both groups. }\end{array}$ \\
\hline $\begin{array}{l}\text { Fearon et al } \\
(2006)\end{array}$ & $\begin{array}{l}\text { Patients with advanced lung or gastrointestinal } \\
\text { cancer }(n=518) \text { were randomised to a double- } \\
\text { blind, placebo-controlled 8-week study of daily } \\
\text { treatment. E1: } 2 \text { g EPA }(n=175) \text {, E2: } 4 \mathrm{~g} \text { EPA } \\
(n=172), \text { C group }(n=171) \text {. }\end{array}$ & $\begin{array}{l}\text { To examine the effects of EPA treatment on } \\
\text { cachexia in cancer patients, by measuring body } \\
\text { weight and composition, CRP, albumin, } \\
\text { appetite, physical functioning, and Karnofsky } \\
\text { performance status. }\end{array}$ & $\begin{array}{l}\text { Nonsignificant weight gain of } 1.2 \mathrm{~kg} \text { in E1 and } \\
0.3 \mathrm{~kg} \text { in E2. It is important to note that } \\
\text { patients with } \mathrm{Gl} \text { cancer gained significant } \\
\text { amount of weight compared with lung cancer } \\
\text { patients who did not. E1 showed a } \\
\text { nonsignificant gain of } 0.9 \mathrm{~kg} \text { in lean body } \\
\text { mass and E2 decreased by } 0.1 \mathrm{~kg} \text {. Physical } \\
\text { function compared with control improved } \\
\text { significantly by } 7 \% \text { in E1 and decreased by } \\
5 \% \text { in E2. }\end{array}$ \\
\hline $\begin{array}{l}\text { Finocchiaro } \\
\text { et al (2012) }\end{array}$ & $\begin{array}{l}\text { Patients with advanced inoperable non-small } \\
\text { cell lung cancer and undertaking } \\
\text { chemotherapy were randomised to a } \\
\text { multicentre, double-blind study to receive } 66 \\
\text { days of daily treatment of: E group: } 4 \text { capsules } \\
\text { of } 510 \mathrm{mg} \text { EPA and } 340 \mathrm{mg} \text { of DHA ( } n=13) \text {. C } \\
\text { group: } 4 \text { capsules of } 850 \mathrm{mg} \text { olive oil }(n=14) \text {. }\end{array}$ & $\begin{array}{l}\text { To examine the effects of EPA + DHA on } \\
\text { inflammatory condition, oxidative and } \\
\text { nutritional status on lung cancer patients } \\
\text { undergoing chemotherapy, by measuring } \\
\text { body weight and oxidative indicators: ROS and } \\
\text { hydroxynonenal levels in plasma, and } \\
\text { inflammatory parameters; CRP, IL-6, PGE } 2 \text { and } \\
\text { TNF- } \alpha \text { levels. }\end{array}$ & $\begin{array}{l}\text { C group had higher levels of CRP, IL-6, } \\
\text { TNF- } \alpha \text {, and PGE } 2 \text { compared with E group, } \\
\text { with significant differences in CRP and IL-6 } \\
\text { levels. Hydroxynonenal and ROS levels were } \\
\text { significantly increased in both the C groups } \\
\text { and decreased in both E groups. }\end{array}$ \\
\hline $\begin{array}{l}\text { Guarcello } \\
\text { et al (2007) }\end{array}$ & $\begin{array}{l}\text { Patients with small cell lung cancer and non- } \\
\text { small cell lung cancer undergoing } \\
\text { chemotherapy ( } n=46 \text { ) were randomised to a } \\
\text { blind, placebo-controlled study to receive } 60 \\
\text { days of treatment with either: E group: energy- } \\
\text { rich oral supplement containing } 2.2 \mathrm{~g} \text { of EPA } \\
\text { ( } n=26 \text { ). C group: energy-rich oral supplement } \\
\text { minus EPA ( } n=20 \text { ). }\end{array}$ & $\begin{array}{l}\text { To evaluate the influence of an EPA-enriched, } \\
\text { energy-dense oral supplement on } \\
\text { inflammatory and nutritional status and on the } \\
\text { OoL of lung cancer patients undergoing } \\
\text { chemotherapy, by measuring body weight, } \\
\text { inflammatory parameters; prealbumin, } \\
\text { transferring, and CRP and QoL using a self- } \\
\text { administered EORTC questionnaire. }\end{array}$ & $\begin{array}{l}\text { Body weight in E group significantly } \\
\text { increased by a median of } 0.9 \mathrm{~kg} \text {, compared } \\
\text { with control that decreased at } 30 \text { days and } \\
\text { then returned to baseline median. Both } \\
\text { groups showed increases in QoL functioning } \\
\text { status and decrease of QoL symptom status, } \\
\text { with significant results in E group. Significant } \\
\text { decrease in E group in CRP levels with } \\
\text { an increase in control. }\end{array}$ \\
\hline $\begin{array}{l}\text { Hall et al } \\
(2008)\end{array}$ & $\begin{array}{l}\text { A 22-year prospective study of American } \\
\text { physicians with annual follow-up, including } \\
\text { food frequency questionnaire and reporting of } \\
\text { new diagnosis of colorectal cancer }(n=22071) \text {. }\end{array}$ & $\begin{array}{l}\text { To examine the relationship of } n-3 \text { and } n-6 \\
\text { PUFAs intake with colorectal cancer risk by } \\
\text { analysing food frequency diaries and diagnosis } \\
\text { of colorectal cancer. }\end{array}$ & $\begin{array}{l}\text { Fish intake inversely correlated with colorectal } \\
\text { cancer risk. Intake of n-3 PUFA and fish may } \\
\text { decrease the risk of colorectal cancer } \\
\text { development. }\end{array}$ \\
\hline
\end{tabular}


Table 1. Continued

\begin{tabular}{|c|c|c|c|}
\hline Author & Design & Objectives & Outcomes \\
\hline $\begin{array}{l}\text { Mantovani } \\
\text { et al (2006) }\end{array}$ & $\begin{array}{l}\text { Patients with a range of cancers }(n=39) \\
\text { partook in an open nonrandomised phase II } \\
\text { study and received a multimodal treatment } \\
\text { consisting of: diet with high polyphenol } \\
\text { content, antioxidant treatment (ALA ( } 300 \mathrm{mg}) \text {, } \\
\text { Vit. E }(400 \mathrm{mg}) \text {, Vit. A ( } 30000 \text { IU), and Vit. C } \\
(500 \mathrm{mg}) \text { ), pharmaconutritional support; EPA } \\
2.2 \mathrm{~g} \text { and DHA } 0.92 \mathrm{~g}), \text { progestagen and Cox-2 } \\
\text { inhibitor. }\end{array}$ & $\begin{array}{l}\text { To assess the efficacy and safety of a } \\
\text { pharmaconutritional supplement containing } \\
\text { antioxidants and drugs, in advanced cancer } \\
\text { patients with from cancer-related anorexia- } \\
\text { cachexia syndrome. Efficacy variables of } \\
\text { disease stability, nutritional functions of } \\
\text { LBM, appetite and grip strength, } \\
\text { inflammatory cytokines, and EORTC } \\
\text { questionnaires were used to assess } \\
\text { these parameters. }\end{array}$ & $\begin{array}{l}\text { Significant increase in body weight, LBM, and } \\
\text { appetite. The IL-6 and TNF- } \alpha \text { significantly } \\
\text { decreased. Significant improvement in QoL } \\
\text { and fatigue. Spearman rank test showed } \\
\text { significant correlation between LBM } \\
\text { differences and IL- } 6 \text { levels. }\end{array}$ \\
\hline $\begin{array}{l}\text { Murphy } \\
\text { et al (2011) }\end{array}$ & $\begin{array}{l}\text { Open-label, non-small cell lung cancer patients } \\
\text { undergoing first-line chemotherapy received } \\
\text { combination of fish oil }(2.5 \mathrm{~g} \text { EPA and DHA per } \\
\text { day + chemotherapy }(n=15) \text { or standard of } \\
\text { care + chemotherapy }(n=31) \text {. }\end{array}$ & $\begin{array}{l}\text { To assess if the combination of fish oil and } \\
\text { chemotherapy was beneficial over the standard } \\
\text { of care with regard to response rate and clinical } \\
\text { benefit from chemotherapy in patients with } \\
\text { non-small cell lung cancer. }\end{array}$ & $\begin{array}{l}\text { Fish oil group had increased response rate } \\
\text { and clinical benefit compared with the control } \\
\text { group. The incidence of dose-limiting toxicity } \\
\text { did not differ between groups. The 1-year } \\
\text { survival tended to be greater in the fish oil } \\
\text { group. Supplementation with fish oil } \\
\text { increased efficacy of first-line chemotherapy } \\
\text { for non-small cell lung cancer compared } \\
\text { with standard of care alone, and may } \\
\text { contribute to increased survival duration } \\
\text { in that population. }\end{array}$ \\
\hline $\begin{array}{l}\text { Murphy } \\
\text { et al (2011) }\end{array}$ & $\begin{array}{l}\text { Patients with non-small cell lung cancer and } \\
\text { naive to or undergoing first-line chemotherapy } \\
\text { consented to receive platinum-based } \\
\text { chemotherapy for }>6 \text { weeks, with fish oil } \\
\text { ( } 2.2 \mathrm{~g} \text { EPA per day; } n=16) \text { supplementation, } \\
\text { or standard of care }(n=24) \text {. }\end{array}$ & $\begin{array}{l}\text { To assess effect of EPA intervention, in } \\
\text { comparison with standard of care/no EPA } \\
\text { intervention, on weight, and body composition } \\
\text { relating to skeletal muscle and adipose tissue } \\
\text { from initiation to completion of chemotherapy. }\end{array}$ & $\begin{array}{l}\text { Patients in the standard of care group } \\
\text { experienced significantly greater weight } \\
\text { loss than the fish oil group, in which } \\
\text { patients with the greatest increase in } \\
\text { plasma EPA concentration experienced } \\
\text { greatest muscle gains. Thus, } 69 \% \text { of EPA } \\
\text { group increased or maintained muscle mass } \\
\text { compared with } 29 \% \text { in standard of care } \\
\text { group. No difference in adipose was } \\
\text { observed. Supplementation of } 2.2 \mathrm{~g} \text { EPA per } \\
\text { day provides benefits over standard of care in } \\
\text { maintenance of weight and body mass } \\
\text { during chemotherapy in this patient } \\
\text { population. }\end{array}$ \\
\hline $\begin{array}{l}\text { Read et al } \\
(2007)\end{array}$ & $\begin{array}{l}\text { Patients with advanced colorectal cancer } \\
\text { receiving chemotherapy }(n=23) \text { partook in } \\
\text { an open-label, phase II study and received } \\
9 \text { weeks of treatment, consisting of a protein } \\
\text { and energy-rich oral supplement containing } \\
2.18 \mathrm{~g} \mathrm{EPA} \mathrm{and} 0.92 \mathrm{~g} \text { DHA. }\end{array}$ & $\begin{array}{l}\text { To assess the effects of EPA (contained in an } \\
\text { energy-rich oral supplement) on nutritional and } \\
\text { inflammatory status, QoL, plasma } \\
\text { phospholipids, and cytokine profiles, in } \\
\text { patients with advanced colorectal cancer who } \\
\text { are undergoing chemotherapy, by measuring } \\
\text { body weight and composition, CRP levels, } \\
\text { dietary intake, plasma phospholipid, and } \\
\text { cytokine levels. }\end{array}$ & $\begin{array}{l}\text { Significant increase in mean body weight by } \\
2.5 \mathrm{~kg} \text { over } 9 \text { weeks. The LBM increased } \\
\text { nonsignificantly by } 1.4 \mathrm{~kg} \text {. The CRP levels } \\
\text { increased from baseline by } 14.9 \mathrm{mgl}^{-1} \text { at } \\
3 \text { weeks and at } 9 \text { weeks had reduced back to } \\
1.2 \mathrm{mgl}^{-1} \text { above baseline. Nonsignificant } \\
\text { improvement in QoL at } 9 \text { weeks. The QoL } \\
\text { measure for energy had significantly } \\
\text { improved. }\end{array}$ \\
\hline $\begin{array}{l}\text { Sawada } \\
\text { et al (2012) }\end{array}$ & $\begin{array}{l}\text { Population-based cohort study }(n=90296) \text {. } \\
\text { Self-administered questionnaire at baseline } \\
\text { and } 5 \text {-year follow-up survey including food } \\
\text { frequency questionnaire. In all, } 33392 \text { subjects } \\
\text { provided blood samples. }\end{array}$ & $\begin{array}{l}\text { To investigate the association of fish and n-3 } \\
\text { PUFA consumption and hepatocellular } \\
\text { carcinoma by analysing food frequency } \\
\text { questionnaires and assessing patient blood } \\
\text { samples. }\end{array}$ & $\begin{array}{l}\text { Among all patients, consumption of } \mathrm{n}-3 \\
\text { PUFA-rich fish and supplements was inversely } \\
\text { associated with hepatocellular carcinoma in a } \\
\text { dose-dependent manner. Reduced } \\
\text { hepatocellular carcinoma risk may be linked to } \\
\text { decreased inflammation caused by higher n-3 } \\
\text { PUFA intake. }\end{array}$ \\
\hline $\begin{array}{l}\text { Sultan et al } \\
\text { (2012) }\end{array}$ & $\begin{array}{l}\text { Subtotal oesophagectomy and total } \\
\text { gastrectomy oesophagogastric cancer patients } \\
(n=192) \text { randomised to } n-3 \text { enteral immune- } \\
\text { enhancing diet or standard enteral nutrition for } \\
7 \text { days before and after surgery, or to } \\
\text { postoperative supplementation alone (control } \\
\text { group). }\end{array}$ & $\begin{array}{l}\text { To assess the effect of } n-3 \text { fatty acids on clinical } \\
\text { outcome and immune function post } \\
\text { oesophagogastric cancer surgery by measuring } \\
\text { morbidity and mortality rates, fatty acid } \\
\text { concentrations, and monocyte and activated } \\
\text { T-lymphocyte levels. }\end{array}$ & $\begin{array}{l}\text { No differences in morbidity, mortality, or } \\
\text { hospital stay between groups. Plasma n-3 } \\
\text { increased in the enteral immunoenhancing } \\
\text { diet. No difference between expression of } \\
\text { monocytes or activated T lymphocytes } \\
\text { between groups. } n-3 \text { supplementation } \\
\text { for } 7 \text { days pre- and post-oesophagogastic } \\
\text { cancer surgery had no overall effect } \\
\text { on immune response or clinical } \\
\text { outcomes despite increased } \\
\text { plasma n-3 levels. }\end{array}$ \\
\hline
\end{tabular}


Table 1. Continued

\begin{tabular}{|c|c|c|c|}
\hline Author & Design & Objectives & Outcomes \\
\hline $\begin{array}{l}\text { Taylor } \\
\text { et al } \\
\text { (2010) }\end{array}$ & $\begin{array}{l}\text { Cancer patients with varying cancers }(n=31) \\
\text { partook in an open-label, single-arm study, and } \\
\text { received } 6 \text { weeks of treatment of } 3 \text { capsules } \\
\text { daily of } 500 \mathrm{mg} \text { capsule containing } 176.5 \mathrm{mg} \\
\text { EPA and } 282.5 \mathrm{mg} \text { DHA. }\end{array}$ & $\begin{array}{l}\text { To assess the effects of a marine phospholipids } \\
\text { (> 50\% containing EPA and DHA) of cachectic } \\
\text { weight loss, appetite, QoL, and fatty acid profile } \\
\text { of blood plasma by measuring body weight, } \\
\text { appetite, and QoL by self-administered } \\
\text { questionnaires, and cytokine and fatty acid } \\
\text { levels in blood of patients with various cancer } \\
\text { types. }\end{array}$ & $\begin{array}{l}\text { Patients reported on the subjective } \\
\text { significance questionnaire, high levels of } \\
\text { improvement in pain reduction, and overall } \\
\text { health, with moderate to high levels in physical } \\
\text { scores. Baseline weight compared with end of } \\
\text { study showed a significant increase; however, } \\
\text { some patients were gaining weight before } \\
\text { study. The CRP showed a slight decrease, and } \\
\text { IL-6 and TNF- } \alpha \text { increased but not significantly. }\end{array}$ \\
\hline $\begin{array}{l}\text { Van Der } \\
\text { Meij } \\
\text { et al } \\
(2012)\end{array}$ & $\begin{array}{l}\text { Patients with stage III non-small cell lung cancer } \\
\text { ( } n=40 \text { ) were randomised to a double-blind, } \\
\text { placebo-controlled, study consisting of } 5 \text { weeks } \\
\text { of treatment of: E group: protein and energy- } \\
\text { rich oral supplement containing } 2.02 \mathrm{~g} \text { EPA and } \\
0.92 \mathrm{~g} \mathrm{DHA}, n=20 \text {. C group: Isocaloric oral } \\
\text { supplement, } n=20 \text {. }\end{array}$ & $\begin{array}{l}\text { To investigate the effects of an oral nutrient } \\
\text { supplement containing n-3 fatty acids on QoL, } \\
\text { performance status, handgrip strength, and } \\
\text { physical activity in patients with NSCLC, by } \\
\text { measuring QoL using the EORTC and by using } \\
\text { specific equipment to measure grip strength } \\
\text { and physical activity. }\end{array}$ & $\begin{array}{l}\text { Group E showed significant increases in } \\
\text { physical function, cognitive function, and a } \\
\text { reduction in nausea/vomiting. n-3 PUFAs may } \\
\text { improve QoL, performance status, and physical } \\
\text { activity in patients with non-small cell lung } \\
\text { cancer undergoing multimodality treatment. }\end{array}$ \\
\hline $\begin{array}{l}\text { Weed } \\
\text { et al } \\
(2011)\end{array}$ & $\begin{array}{l}\text { Patients with squamous cell cancer of the head } \\
\text { and neck who were undergoing major resection } \\
\text { surgery ( } n=38 \text { ), partook in a single-centre, } \\
\text { open-label, single-arm study, and received } \\
\text { treatment } 2 \text { weeks before surgery and during, } \\
\text { consisting of: protein and energy-dense oral } \\
\text { supplement containing } 2.16 \mathrm{~g} \text { EPA and } 0.92 \mathrm{~g} \\
\text { DHA. }\end{array}$ & $\begin{array}{l}\text { To assess the effects of an oral supplement } \\
\text { containing EPA on cancer-associated weight } \\
\text { loss mediated by an inflammatory response to } \\
\text { cancer on body weight and composition by } \\
\text { measuring body weight and composition. }\end{array}$ & $\begin{array}{l}\text { Mean weight from trial entry to hospital } \\
\text { admission was } 0.71 \mathrm{~kg} \text { and from admission to } \\
\text { discharge was } 0.66 \mathrm{~kg} \text {; these results were not } \\
\text { significant. Lean body mass had a significant } \\
\text { increase during admission to discharge, with a } \\
\text { mean gain of } 3.2 \mathrm{~kg} \text {. Fat mass also showed a } \\
\text { significant decrease of } 3.19 \mathrm{~kg} \text { during the same } \\
\text { period. }\end{array}$ \\
\hline
\end{tabular}

provides an important target for future research. The n-3 LCPUFAs, in particular EPA and DHA, have been implicated to have an inhibitory effect on pro-inflammatory cytokines, subsequently reducing inflammation. Supplementation with EPA/DHA increases acetylcholine levels, in turn blocking the release of cytokines such as tumour necrosis factor- $\alpha$ (TNF- $\alpha$ ), interlukin-1, and interlukin-6, with the replacement of AA by EPA and DHA causing altered production of eicosanoids towards less inflammatory products (Calder, 2002; Arab et al, 2006). Inflammation caused by redox imbalance has also been shown to be reduced by EPA/DHA supplementation via decreased production of ROS by COX-2 and upregulation of antioxidant systems (Arab et al, 2006; Kim and Chung, 2007). This anti-inflammatory approach is further supported by the use of EPA and DHA in conjunction with Cox-2 inhibitors in supportive cancer care in order to reduce symptom clusters (Cerchietti et al, 2007). Lung cancer patients given either fish oil ( $1 \mathrm{~g}, 18 \% \mathrm{EPA}$ and $12 \% \mathrm{DHA}$ ) and celecoxib or fish oil with placebo over a 6-week period showed significantly improved appetite, less fatigue, and lower CRP levels than at baseline. The group receiving the combined treatment group also showed increased body weight and muscle strength compared with baseline, and lower CRP levels with increased body weight and muscle strength compared with fish oil alone. The addition of celecoxib to fish oil modulates eicosanoid metabolism, reducing symptoms of secondary syndromes in cancer (Cerchietti et al, 2007), in particular those associated with inflammation, and provides a strong argument for the use of fish oil as part of a multimodal therapy for the treatment of these conditions.

There is a high prevalence of depression in cancer patients (10-30\%) compared with the general population (5-10\%), with depression leading to reductions in drug compliance and effectiveness (Chochinov, 2001). There is some difficulty in distinguishing between reactive demoralisation and clinical depression, or the overlapping symptoms of illness and depression, which may contribute to clinical depression being underrecognised and undertreated in patients with cancer (Raison and Miller, 2003). However, the increased expression of shared inflammatory cytokine pathways may lead to increased prevalence of clinical depression in a cancer patient population (Raison and Miller, 2003). As such, treatments that address pro-inflammatory cytokine activity in cancer, such as supplementation with EPA or DHA, may also contribute towards the alleviation of clinical depression in susceptible patients.

\section{MARINE PUFAS AND SECONDARY CANCER} COMPLICATIONS

Complications associated with cancer vary between patients, tumour type, and disease stage, and can take a number of forms including infection, pain, nausea, fatigue, anxiety, and cachexia (Cerchietti et al, 2007).

Cancer cachexia is a complication of cancer that occurs in patients with advanced solid tumour cancers (Tisdale, 2009). Cachexia is a multidimensional condition, characterised by involuntary weight loss of $>5 \%$, that involves a number of tumour and host factors in its progression. These include tumourinduced pro-cachectic and pro-inflammatory responses, systemic inflammation, and altered metabolism, leading to a loss of skeletal muscle and adipose tissue (Donohoe et al, 2011; Fearon et al, 2011), and can severely affect QoL through fatigue, weakness, and reduced physical activity (Tisdale, 2009), with patients facing a poor prognosis (Guarcello et al, 2007).

The ubiquitin-proteasome pathway is one pathway responsible for the breakdown of proteins, and may be initiated by tumourderived factors such as TNF- $\alpha$ (Sullivan-Gunn et al, 2011). Downstream factors such as AA and reactive oxygen species have also been implicated in its induction (Sullivan-Gunn et al, 2011). 
The weight loss occurring in cachexia is also attributed to the loss of adipose tissue via lipolysis. This is initiated by lipid-mobilising factor (LMF), and the tumour and host factor zinc- $\alpha_{2}$-glycoprotein (ZAG) that are overexpressed in cachectic patients (Russell and Tisdale, 2005).

In addition to being used as an adjuvant to cancer therapy, n-3 LCPUFAs have been tested to alleviate the symptoms of cancer cachexia (Table 1). Weed et al (2011) demonstrated that EPA supplementation was significantly associated with an increase in lean body mass in cachectic patients, a gain that may be attributed to the downregulation of the ubiquitin-proteasome pathway (Tisdale, 2009). The EPA supplementation of $2.2 \mathrm{~g} \mathrm{day}^{-1}$ over treatment duration has also been shown to assist in the maintenance of weight and muscle mass in NSCLC patients undergoing chemotherapy compared with patients undergoing chemotherapy without EPA supplementation (Murphy et al, 2011). The anti-inflammatory properties of EPA have also been implicated in reducing acute-phase proteins, such as CRP, that may contribute to muscle wasting in cachexia (Murphy et al, 2011). A study by Guarcello et al (2007) showed a significant decrease in CRP levels in cachectic patients supplemented with EPA, whereas the levels in control group increased.

In studies of varying cancer types, EPA has shown significant (Guarcello et al, 2007) and nonsignificant (Fearon et al, 2006; Weed et al, 2011) increases in body weight, indicating that the type of cancer may also play a role in EPA responsiveness, with gastrointestinal cancer patients gaining a significant amount of weight compared with the lung cancer patients (Fearon et al, 2006). The weight gain may be attributed to a number of different mechanisms, including increases in lean body mass and the downregulation of ZAG (Russell and Tisdale, 2005) via the interference with glucocorticoid signalling (Tisdale, 2009), reducing the degradation of adipose tissue.

Despite several clinical studies showing no statistically significant gain in weight and lean body mass, it is important to note that many studies do report improved QoL (Fearon et al, 2006; van der Meij et al, 2012). In a study of EPA and DHA, patients reported high level of improvements in pain and overall health and a significant increase in body weight (Taylor et al, 2010). Increased total energy expenditure and physical activity levels have been observed in patients taking EPA supplements in trials, indicating improved physical capacity (Moses et al, 2004; van der Meij et al, 2012). Any improvement the physical activity, ability to perform daily tasks, fatigue, weakness, and overall health of patient greatly enhances their QoL, and leads to improved prognosis (Moses et al, 2004; Donohoe et al, 2011; van der Meij et al, 2012). Thus, n-3 LCPUFAs may be a consideration as part of a multimodal approach to treat cancer and associated complications such as cachexia (Colomer et al, 2007).

\section{LIMITATIONS OF MARINE PUFA USE}

Although marine PUFAs have been shown to have considerable potential to prevent and augment the treatment of cancer and complications such as cachexia, there are still a number of limitations associated with their use in cancer patients. Because of a significant number of cancer patients experiencing nausea, the consumption of therapeutic doses of fish oil ( $>3 \mathrm{~g}$ per day) or more purified EPA/DHA ( $>2 \mathrm{~g}$ EPA, $>1.4 \mathrm{~g}$ DHA per day) may be impractical, because of the commonly experienced side effect of 'fishy' reflux experienced by many patients consuming fish oil or EPA/DHA supplements. In addition, investigations by Roodhart et al (2011) raised the question as to whether all PUFAs provide benefit, particularly in patients receiving chemotherapy (Roodhart et al, 2011). They suggest that the PUFAs 12-oxo-5,8, 10-heptadecatrienoic acid (KHT (n-6)) and hexadeca-4,7,10, 13-tetraenoic acid (16:4(n-3)) may be involved in the induction of resistance to chemotherapy. Although these compounds may have a profound pharmacological effect, others have described their abundance to be low, with analyses of various fish oil preparations placing them between $0 \%$ and $1.56 \%$ of total lipid content (Osman et al, 2001; Wolyniak et al, 2005). Murphy et al 2012) have previously highlighted the inconsistencies presented by these claims when compared with the published literature, and the concern that recommending the reduction of essential fatty acids may have a detrimental effect in this patient population. The discovery that KHT and 16:4(n-3) may play a role in chemotherapy resistance highlights that there is a need for supplementation of marine PUFA supplements to be carefully assessed, with a focus on promoting purified n-3 LCPUFA supplements over less refined whole fish oil, rather than the broad discouragement of this often beneficial augmentation to treatment in patients undergoing chemotherapy.

\section{CONCLUSIONS}

Polyunsaturated fatty acids derived from marine sources, including EPA and DHA, are widely consumed as supplements within the community, including cancer patients. The prescription of n-3 LCPUFAs in a therapeutic context is also increasing in patients receiving treatment for a range of cancer types. There is also now sufficient literature to suggest that the use of supplements containing EPA and DHA may have potential as an effective adjuvant to chemotherapy treatment and may help ameliorate some of the secondary complications associated with cancer. Although this review was not exhaustive, our investigations indicate that supplementation with fish oil ( $>3 \mathrm{~g}$ per day) or EPA/DHA ( $>1 \mathrm{~g} \mathrm{EPA}$ and $>0.8 \mathrm{~g}$ DHA per day) is associated with positive clinical outcomes. However, other components of fish oil may be detrimental to cancer treatment, and further research is still required to determine the mechanisms by which both marinederived n-3 PUFAs and other fish-oil derived compounds are mediating their effects.

\section{REFERENCES}

AICR and WCRF Research (2007) Food, Nutrition, Physical Activity, and the Prevention of Cancer: A Global Perspective. American Institute for Cancer Research: Washington, DC, 2.

Alfano CM, Imayama I, Neuhouser ML, Kiecolt-Glaser JK, Smith AW, Meeske K, McTiernan A, Bernstein L, Baumgartner KB, Ulrich CM, Ballard-Barbash R (2012) Fatigue, inflammation, and omega-3 and omega-6 fatty acid intake among breast cancer survivors. J Clin Oncol 30: $1280-1287$.

Arab K, Rossary A, Flourie F, Tourneur Y, Steghens JP (2006) Docosahexaenoic acid enhances the antioxidant response of human fibroblasts by upregulating gamma-glutamyl-cysteinyl ligase and glutathione reductase. $\mathrm{Br} J$ Nutr 95: 18-26.

Baracos VE, Mazurak VC, Ma DW (2004) n-3 Polyunsaturated fatty acids throughout the cancer trajectory: influence on disease incidence, progression, response to therapy and cancer-associated cachexia. Nutr Res Rev 17: 177-192.

Bayram I, Erbey F, Celik N, Nelson JL, Tanyeli A (2009) The use of a protein and energy dense eicosapentaenoic acid containing supplement for malignancy-related weight loss in children. Pediatr Blood Cancer 52: 571-574.

Bougnoux P, Hajjaji N, Ferrasson MN, Giraudeau B, Couet C, Le Floch O (2009) Improving outcome of chemotherapy of metastatic breast cancer by docosahexaenoic acid: a phase II trial. Br J Cancer 101: 1978-1985.

Calder PC (2002) Dietary modification of inflammation with lipids. Proc Nutr Soc 61: 345-358. 
Cerchietti LC, Navigante AH, Castro MA (2007) Effects of eicosapentaenoic and docosahexaenoic $\mathrm{n}-3$ fatty acids from fish oil and preferential Cox-2 inhibition on systemic syndromes in patients with advanced lung cancer. Nutr Cancer 59: 14-20.

Chochinov HM (2001) Depression in cancer patients. Lancet Oncol 2: 499-505.

Colomer R, Moreno-Nogueira JM, Garcia-Luna PP, Garcia-Peris P, Garcia-de-Lorenzo A, Zarazaga A, Quecedo L, del Llano J, Usan L, Casimiro C (2007) N-3 fatty acids, cancer and cachexia: a systematic review of the literature. Br J Nutr 97: 823-831.

Das UN (2011) Essential fatty acids and their metabolites as modulators of stem cell biology with reference to inflammation, cancer, and metastasis. Cancer Metastasis Rev 30: 311-324.

Donohoe CL, Ryan AM, Reynolds JV (2011) Cancer cachexia: mechanisms and clinical implications. Gastroenterol Res Pract 2011: 601434.

Elia M, Van Bokhorst-de van der Schueren MA, Garvey J, Goedhart A, Lundholm K, Nitenberg G, Stratton RJ (2006) Enteral (oral or tube administration) nutritional support and eicosapentaenoic acid in patients with cancer: a systematic review. Int J Oncol 28: 5-23.

Fearon K, Strasser F, Anker SD, Bosaeus I, Bruera E, Fainsinger RL, Jatoi A, Loprinzi C, MacDonald N, Mantovani G, Davis M, Muscaritoli M, Ottery F, Radbruch L, Ravasco P, Walsh D, Wilcock A, Kaasa S, Baracos VE (2011) Definition and classification of cancer cachexia: an international consensus. Lancet Oncol 12: 489-495.

Fearon KC, Barber MD, Moses AG, Ahmedzai SH, Taylor GS, Tisdale MJ, Murray GD (2006) Double-blind, placebo-controlled, randomized study of eicosapentaenoic acid diester in patients with cancer cachexia. J Clin Oncol 24: 3401-3407.

Finocchiaro C, Segre O, Fadda M, Monge T, Scigliano M, Schena M, Tinivella M, Tiozzo E, Catalano MG, Pugliese M, Fortunati N, Aragno M, Muzio G, Maggiora M, Oraldi M, Canuto RA (2012) Effect of n-3 fatty acids on patients with advanced lung cancer: a double-blind, placebo-controlled study. Br J Nutr 108: 327-333.

Gerber M (2012) Omega-3 fatty acids and cancers: a systematic update review of epidemiological studies. Br J Nutr 107(Suppl 2): S228-S239.

Guarcello M, Riso S, Buosi R, d'Andrea F (2007) EPA-enriched oral nutritional support in patients with lung cancer: effects on nutritional status and quality of life. Nutr Ther Metab 25: 25-30.

Gurr M, Harwood J, Frayn K (2008) Lipid Biochemistry. An Introduction: Hoboken, Wiley-Blackwell.

Hall MN, Chavarro JE, Lee IM, Willett WC, Ma J (2008) A 22-year prospective study of fish, n-3 fatty acid intake, and colorectal cancer risk in men. Cancer Epidemiol Biomarkers Prev 17: 1136-1143.

Kim YJ, Chung HY (2007) Antioxidative and anti-inflammatory actions of docosahexaenoic acid and eicosapentaenoic acid in renal epithelial cells and macrophages. J Med Food 10: 225-231.

Mantovani G, Maccio A, Madeddu C, Gramignano G, Lusso MR, Serpe R, Massa E, Astara G, Deiana L (2006) A phase II study with antioxidants, both in the diet and supplemented, pharmaconutritional support, progestagen, and anti-cyclooxygenase- 2 showing efficacy and safety in patients with cancer-related anorexia/cachexia and oxidative stress. Cancer Epidemiol Biomarkers Prev 15: 1030-1034.

Moses AW, Slater C, Preston T, Barber MD, Fearon KC (2004) Reduced total energy expenditure and physical activity in cachectic patients with pancreatic cancer can be modulated by an energy and protein dense oral supplement enriched with n-3 fatty acids. Br J Cancer 90: 996-1002.

Murphy RA, Clandinin MT, Chu QS, Arends J, Mazurak VC (2012) A fishy conclusion regarding n-3 fatty acid supplementation in cancer patients. Clin Nutr; e-pub ahead of print, 15 June 2012.

Murphy RA, Mourtzakis M, Chu QS, Baracos VE, Reiman T, Mazurak VC (2011) Supplementation with fish oil increases first-line chemotherapy efficacy in patients with advanced nonsmall cell lung cancer. Cancer 117: 3774-3780.

Murphy RA, Mourtzakis M, Chu QS, Baracos VE, Reiman T, Mazurak VC (2011) Nutritional intervention with fish oil provides a benefit over standard of care for weight and skeletal muscle mass in patients with nonsmall cell lung cancer receiving chemotherapy. Cancer 117: 1775-1782.

Murphy RA, Yeung E, Mazurak VC, Mourtzakis M (2011) Influence of eicosapentaenoic acid supplementation on lean body mass in cancer cachexia. Br J Cancer 105: 1469-1473.

Osman H, Suriah A, Law E (2001) Fatty acid composition and cholesterol content of selected marine fish in Malaysian waters Food Chem 73: 55-60.

Raison CL, Miller AH (2003) Depression in cancer: new developments regarding diagnosis and treatment. Biol Psychiatry 54: 283-294.

Read JA, Beale PJ, Volker DH, Smith N, Childs A, Clarke SJ (2007) Nutrition intervention using an eicosapentaenoic acid (EPA)-containing supplement in patients with advanced colorectal cancer. Effects on nutritional and inflammatory status: a phase II trial. Support Care Cancer 15: 301-307.

Roodhart JMLG, Daenen EC, Stigter HJ, Prins J, Gerrits JM, Houthuijzen MG, Gerritsen HS, Schipper MJ, Backer M, van Amersfoort JS, Vermaat P, Moerer K, Ishihara E, Kalkhoven JH, Beijnen PW, Derksen RH, Medema AC, Martens AB, Brenkman EE, Voest (2011) Mesenchymal stem cells induce resistance to chemotherapy through the release of platinuminduced fatty acids. Cancer Cell 20: 370-383.

Russell ST, Tisdale MJ (2005) Effect of eicosapentaenoic acid (EPA) on expression of a lipid mobilizing factor in adipose tissue in cancer cachexia. Prostaglandins Leukot Essent Fatty Acids 72: 409-414.

Sawada N, Inoue M, Iwasaki M, Sasazuki S, Shimazu T, Yamaji T, Takachi R, Tanaka Y, Mizokami M, Tsugane S (2012) Consumption of n-3 fatty acids and fish reduces risk of hepatocellular carcinoma. Gastroenterology 142(7): 1468-1475.

Schmitz G, Ecker J (2008) The opposing effects of n-3 and n-6 fatty acids. Prog Lipid Res 47: 147-155.

Sullivan-Gunn MJ, Campbell-O’Sullivan SP, Tisdale MJ, Lewandowski PA (2011) Decreased NADPH oxidase expression and antioxidant activity in cachectic skeletal muscle. J Cachexia Sarcopenia Muscle 2: 181-188.

Sultan JSM, Griffin F, Di Franco JA, Kirby BK, Shenton CJ, Seal P, Davis YK, Viswanath SR, Preston N, Hayes (2012) Randomized clinical trial of omega-3 fatty acid-supplemented enteral nutrition versus standard enteral nutrition in patients undergoing oesophagogastric cancer surgery. Br J Surg 99: 346-355.

Taylor LAL, Pletschen J, Arends C, Unger U, Massing (2010) Marine phospholipids-a promising new dietary approach to tumor-associated weight loss. Support Care Cancer 18: 159-170.

Tisdale MJ (2009) Mechanisms of cancer cachexia. Physiol Rev 89: $381-410$.

van der Meij BS, Langius JA, Spreeuwenberg MD, Slootmaker SM, Paul MA, Smit EF, van Leeuwen PA (2012) Oral nutritional supplements containing $\mathrm{n}-3$ polyunsaturated fatty acids affect quality of life and functional status in lung cancer patients during multimodality treatment: an RCT. Eur J Clin Nutr 66: 399-404.

Wall R, Ross RP, Fitzgerald GF, Stanton C (2010) Fatty acids from fish: the anti-inflammatory potential of long-chain omega-3 fatty acids. Nutr Rev 68: $280-289$.

Weed HG, Ferguson ML, Gaff RL, Hustead DS, Nelson JL, Voss AC (2011) Lean body mass gain in patients with head and neck squamous cell cancer treated perioperatively with a protein- and energy-dense nutritional supplement containing eicosapentaenoic acid. Head Neck 33: 1027-1033.

Wolyniak CJ, Brenna JT, Murphy KJ, Sinclair AJ (2005) Gas chromatographychemical ionization-mass spectrometric fatty acid analysis of a commercial supercritical carbon dioxide lipid extract from New Zealand green-lipped mussel (Perna canaliculus). Lipids 40: 355-360.

(c) (i) (2) (2) This work is licensed under the Creative Commons (c) At NG SA Atribution-NonCommercial-Share Alike 3.0 Unported License. To view a copy of this license, visit http://creativecommons. org/licenses/by-nc-sa/3.0/ 